\title{
IMPLIKASI IDEOLOGI GENDER DALAM HUKUM ADAT BALI (STUDI DI KOTA DENPASAR)
}

\author{
Oleh: \\ Ni Nyoman Sukerti', I Gusti Ayu Agung Ariani², \\ I Gst. A. A.Ari Krisnawati ${ }^{3}$
}

\begin{abstract}
Customary law is the law of life and as a guideline to behave in social life. While the government through Presidential Decree No. 9 of 2000 on Gender Pengharusutaan in National Development. In connection with these two problem are; 1). What is the meaning of the gender ideology? and 2). How the ideological implications of the customary law of Bali? This study is a socio-legal, where field data as primary data. The results of the study addressed that there are two groups; The first group's view justify Balinese customary law is sound and reflects the uniqueness of Balinese society, women are not involved in decision-making in the family, a decision was taken on the deal man. In the field of inheritance girls are not taken into account. So the first group did not reflect the views of gender ideology, while the second group's view, gave the reason that customary law is difficult to change, to change requires public awareness, awig-awig has not set things up in accordance with the development of society and legislation can be made perarem. Most respondents have not gender responsive and only a small portion gender responsive and progressive-minded. Thus gender ideology customary law is not implicated in Bali. Factors that become barriers that the legal culture of the Balinese people, the patriarchal customary law is still strong binding Balinese life. The conclusion that the meaning of gender ideology implies equality of men and women and it is not affected by the customary law of Bali, because of the legal culture of society and customary law still strong binding.
\end{abstract}

Keywords: implications, gender ideology, customary law Bali.

\footnotetext{
Abstrak

Hukum adat adalah hukum kehidupan dan sebagai pedoman untuk berperilaku dalam kehidupan sosial. Sedangkan pemerintah melalui Keputusan Presiden Nomor 9 Tahun 2000 tentang Kesehatan Jender dalam Pembangunan Nasional. Sehubungan dengan kedua masalah tersebut adalah; 1). Apa arti ideologi gender? Dan 2). Apa implikasi ideologis hukum adat Bali? Penelitian ini bersifat sosiolegal, dimana data lapangan sebagai data primer. Hasil penelitian menyebutkan bahwa ada dua kelompok; Pandangan kelompok pertama tentang membenarkan

1 Penulis Pertama adalah Dosen Fakultas Hukum Universitas Udayana, Denpasar Bali, Email: nyomansukerti10@yahoo.com

2 Penulis Kedua adalah Dosen Fakultas Hukum Universitas Udayana, Denpasar Bali, Email:oka.ariani@ yahoo.com.

3 Penulis Ketiga adalah Dosen Fakultas Hukum Universitas Udayana, Denpasar Bali, Email:ary_ krislaw@yahoo.com
} 
hukum adat Bali adalah suara dan mencerminkan keunikan Bali, wanita tidak terlibat dalam pengambilan keputusan di dalam keluarga, sebuah keputusan dibuat berdasarkan kesepakatan manusia. Di bidang warisan anak perempuan tidak diperhitungkan. Jadi kelompok pertama tidak mencerminkan pandangan ideologi gender, sedangkan pandangan kelompok kedua, dengan alasan bahwa hukum adat sulit untuk berubah, untuk berubah membutuhkan kesadaran masyarakat, awig awig tidak mengatur segala sesuatu sesuai dengan perkembangan masyarakat. Dan perundang-undangan bisa dibuat perarem. Sebagian besar responden belum responsif terhadap gender dan hanya sedikit yang responsif terhadap gender dan progresif. Dengan demikian ideologi gender hukum adat tidak dilibatkan di Bali. Faktor-faktor yang menghambat budaya hukum masyarakat Bali, hukum adat patriarkhi masih mengikat kehidupan masyarakat Bali yang kuat. Kesimpulan bahwa makna ideologi gender menyiratkan kesetaraan laki-laki dan perempuan dan tidak terpengaruh oleh hukum adat Bali, karena budaya hukum masyarakat dan hukum adat yang mengikat.

\section{Kata kunci: implikasi, ideologi gender, hukum adat Bali.}

\section{PENDAHULUAN}

Bangsa Indonesia adalah bangsa majemuk yang terdiri dari suku bangsasuku bangsa, dan masing-masing suku bangsa tersebut mempunyai adat dan budaya sendiri-sendiri. Adat dan budaya tersebut sebagai pedoman atau pengikat dalam bertingkah laku menjalani kehidupan. Masingmasing suku bangsa atau masyarakat mempunyai aturan-aturan tentu sebagai benteng untuk melindungi kelangsungan masyarakat yang bersangkutan, salah satunya adalah masyarakat Bali.

Masyarakat Bali adalah masyarakat yang terbuka, walaupun demikian sangat menjunjung tinggi adat dan budaya. Artinya masuknya ideologi atau dari luar tidak serta merta ditolak melainkan tetap diterima tetapi penerimaan mana dilakukan secara selektif. Dengan cara demikian masyarakat Bali di satu sisi tetap mempertahankan adat dan budaya termasuk hukum adatnya tetapi menerima secara selektif ideologi atau budaya luar.

Masyarakat Bali yang dimaksudkan adalah masyarakat Bali Hindu yang menganut sistem kekeluargaan patrilineal (patriarchaat), yang lebih dikenal dengan nama sistem "purusa". Pada sistem kekeluargaan ini kedudukan laki-laki sangat tinggi dan pegang peran yang sangat kuat dalam segala aspek kehidupan baik dalam keluarga, maupun masyarakat, yang paling ditekankan di sini adalah dalam hal membuat aturan sebagai pedoman kehidupan bermasyarakat. Aturan yang dimaksud adalah hukum adat itu sendiri. Dalam membuat aturan hukum perempuan sebagai warga adat tidak pernah dilibatkan, dengan demikian perempuan hanya melaksanakan apa yang telah dibuat dan diputuskan oleh laki-laki. 
Hukum adat sebagai hukum yang di konstruksi oleh masyarakat (laki-laki) yang secara normatif masih sangat bias gender bahkan dapat dikatakan diskriminasi gender terutama dalam hukum keluarga dan hukum waris. Inimencerminkan bahwa budaya patriarkhi masih sangat kuat mempengaruhinya bahkan ideologi patriarkhi begitu kuat mengikat masyarakat Bali Hindu. Masyarakat Bali sangat taat pada hukum adatnya, walaupun demikian tidak berarti masyarakat Bali anti akan perubahan atau perkembangan. Masyarakat Bali sangat cepat mengalami perubahan dalam berbagai hal, akan tetapi dalam bidang hukum adat dapat dikatakan sangatsulituntukmelakukanperubahan bahkan dapat dikatakan dalam posisi stagnan. Terkait dengan hal itu, Pemerintah dengan Instruksi Presiden Nomor 9 Tahun 2000 (Selanjutnya disingkat: Inpres No. 9 Th 2000) tentang Pedoman Pengharusutamaan Gender Dalam Pembangunan Nasional, mencanangkan terwujudnya kesetaraan dan keadilan gender dalam kehidupan berkeluarga, bermasyarakat, berbangsa, dan bernegara.

Sehubungan dengan keluarnya Inpres No. 9 Tahun 2000 tersebut, maka dapat diasumsikan akan berpengaruh pada kehidupan masyarakat patrilineal di Bali yang memeluk agama Hindu. Masyarakat Bali Hindu menjunjung tinggi hukum adat yang begitu kuat mengikat. Hukum adat sebagai hukum lokal tidak searah dengan aturan yang lebih tinggi, yang dalam hal ini adalah hukum negara. Terkait dengan hal itu maka di sinilah letak persoalannya, di satu sisi hukum adat sebagai pedoman hidup dalam bermasyarakat bagi masyarakat Bali Hindu demikian kuat mengikat yang masih diskriminatif gender, disisi lain ada aturan pemerintah yang bertujuan mewujudkan kesetaraan dan keadilan gender dalam kehidupan berkeluarga dan bermasyarakat yang mesti dilakukan. Terkait dengan hal itulah maka penelitian ini menjadi penting untuk dilakukan mengingat berlakunya dualisme hukum yang ideologinya tidak sejalan yakni hukum adat dengan ideologi patriarkhi dimana kekuasaan berada di tangan laki-laki dan hukum negara dengan ideologi kesetaraan dan keadilan gender.

Bertitik tolak dari latar belakang tersebut di atas, dapat dirumuskan permasalahan yang akan diteliti dalam penelitian ini sebagai berikut:

1. Apa makna dari ideologi gender tersebut?

2. Bagaimana implikasi ideologi gender dalam Hukum Adat Bali dewasa ini?

Terkait permasalahan pertama, akan diuraikan tentang makna dari ideologi gender tersebut. Apa makna dari pada ideologi gender tersebut. Makna ideologi gender adalah menyangkut kesetaraan dan keadilan gender dalam aspek-aspek kehidupan antara laki-laki dan perempuan, sementara itu dalam hukum adat Bali 
sangat kental dan kuat dipengaruhi oleh ideologi patriarkhi yang memposisikan laki-laki sangat tinggi atau superior terhadap perempuan.

Dalam permasalahan kedua, akan dibahas mengenai implikasi ideologi gender dalam hukum adat Bali. Adapun yang dimaksudkan di sini adalah sudah atau belum adanya implikasi ideologi gender dalam hukum adat Bali dan faktor-faktor yang menjadi penyebabnya baik faktorfaktor yang mendukung maupun faktor yang menjadi penghambatnya.

Tujuan umum dari penelitian ini adalah untuk mengetahui sejauh mana makna ideologi gender dalam realitanya diketahui oleh masyarakat Bali, sedangkan tujuan khususnya adalah untuk mengetahui makna ideologi gender dalam hukum adat Bali. Di samping itu juga untuk mengetahui sudah atau belum adanya implikasi ideologi gender dalam hukum adat Bali dan faktor-faktor apa saja yang menjadi penyebabnya baik yang menghambat maupun yang mendukungnya.

\section{METODE PENELITIAN}

Penelitian hukum dari segi jenisnya dikelompokkan menjadi dua yaitu penelitian hukum normatif dan penelitian hukum empiris. Terkait hal itu, Amirudin mengelompokkan penelitian hukum dalam dua kelompok yaitu penelitian hukum normatif (doktrinal) dan penelitian hukum sosiologis (socio legal research) ${ }^{1}$

Penelitian tentang implikasi ideologi gender dalam hukum adat Bali (Studi di Kota Denpasar) merupakan penelitian hukum empiris atau sociolegal reseacht. Penelitian ini dilakukan sehubungan dengan dikeluarkannya Inpres No. 9 Tahun 2000. Dalam penelitian hukum empiris dimana data lapangan merupakan data primer. Penelitian ini tidak akan menguji hipotesis, akan tetapi menggali informasi sebanyak mungkin sehubungan implikasi gender dalam masyarakat adat Bali. Meskipun dalam penelitian ini memakai datang lapangan sebagai data primer akan tetapi tidak dapat lepas dari data sekunder, oleh karena itu setiap penelitian hukum empiris pasti diawali dengan data sekunder atau data pustaka sebagai premis normatif.

Dalam penelitian hukum empiris, dimana data yang digali adalah tentang bekerjanya hukum dalam masyarakat. Dengan demikian maka penelitian ini mengutamakan data lapangan sebagai data primer dan data pustaka sebagai data sekunder. Data primer diperoleh dari sumber data lapangan di wilayah Kota Denpasar tentunya dalam lingkup desa pakraman karena menyangkut hukum adat dalam kaitan ideologi gender. Sebagai lokasi penelitian ditentukan secara purposif dengan dasar pertimbangan bahwa Kota Denpasar yang sekaligus sebagai

1 Amiruddin, Zainal Asikin, 2008, Pengantar Metode Penelitian Hukum, PT Raja Grafindo Persada, Jakarta, hlm.110. 
pusat Pemerintahan Propinsi Bali, dimana kondisi masyarakatnya relatif lebih maju dengan tingkat pendidikan lebih tinggi dibandingkan dengan daerah lainya di Bali. Di samping itu warga masyarakatnya juga sangat heterogen. Penentuan responden ditentukan dengan teknik snow ball (bola salju) dan responden yang dipilih adalah tokoh masyarakat, agama, dan beberapa warga masyarakat umum. Hal ini dilakukan mengingat faktor waktu, tenaga, dan tentunya juga biaya.

Data sekunder diperoleh dari penelusuran bahan-bahan tertulis atau dokumen-dokumen yang memuat informasi yang relevan dengan permasalahan yang diangkat. Bahan hukum yang digunakan dalam penelitian ini adalah literatur-literatur hukum yang dapat menjelaskan konsep-konsep hukum adat secara umum dan hukum adat Bali khususnya. Di samping itu juga dibutuhkan literatur non hukum karena penelitian ini berkaitan dengan implikasi ideologi gender dalam hukum adat Bali. Jadi literatur non hukum (literatur terkait gender) juga perlu dalam mengkaji implikasi ideologi gender dalam hukum adat.

Untuk mendapatkan data atau informasi yang akurat, teknik pengumpulan data primer yang digunakan dalam penelitian ini adalah dengan wawancara. Wawancara dilakukan dengan memakai alat bantu, yang dalam hal ini berupa pedoman pertanyaan (interview guide), sementara data sekunder (baik bahan hukum maupun non hukum) dihimpun dengan cara sistem kartu yaitu dengan cara mencatat bahan yang dibutuhkan seperti nama, tahun, judul buku, penerbit dan tempat diterbitkan, dan halaman.

Pengolahan dan analisis data yang sudah dikumpulkan, dilakukan dengan menggunakan metode yang bersifat kualitatif dilengkapi dengan analisis situasional. Metode ini akan dapat menunjukkan tentang implikasi ideologi gender dalam hukum adat pada masyarakat adat di Bali yang begitu kuat menghormati dan mempertahankan hukum adat dalam kehidupan bermasyarakat. Sementara hasilnya disajikan secara deskriptis analitis.

\section{HASIL DAN PEMBAHASAN}

\subsection{Makna Ideologi Gender Dan} Hukum Adat Bali.

Sebelum sampai pada pengertian gender, terlebih dahulu akan dikemukakan pengertian seks dan kodrat. Seks adalah mengacu pada perbedaan jenis kelamin laki-laki dan perempuan atau perbedaan jenis kelamin secara biologis. Sementara kodrat adalah ciri-ciri yang melekat pada manusia sebagai pemberian atau ciptaan Tuhan Yang Maha Kuasa. Sebagai pemberian Tuhan maka bersifat statis dan berlaku universal di seluruh dunia tanpa kecuali. Oleh 
karenanya tidak dapat berubah, diubah dan dipertukarkan.

Contoh si A pada saat lahir berjenis kelamin laki-laki dan sampai mati tetap berjenis kelamin laki-laki, demikian juga si B pada saat lahir berjenis kelamin perempuan dan sampai mati tetap berjenis kelamin perempuan. Terkait dengan hal itu, Tri Marhaeni Pudji Astuti mengemukakan bahwa kodrat itu ketetapan dari Tuhan yang tidak bisa diubah, misalnya jenis kelamin².

Konsep gender dirumuskan pada I Umum angka 3 Inpres No. 9 Tahun 2000 adalah konsepyang mengacu pada peran-peran dan tanggung jawab lakilaki dan perempuan yang terjadi akibat dari dan dapat berubah oleh keadaan sosial budaya masyarakat. Sementara Mansour Fakih mengkonsepkan gender adalah sifat yang melekat pada kaum laki-laki maupun perempuan yang dikonstruksi secara sosial maupun kultural ${ }^{3}$. Mencermati konsep gender tersebut di atas maka gender adalah suatu konsep tentang laki-laki dan perempuan yang dikonstruksi berdasarkan social budaya. Sosial budaya suatu masyarakat yang satu sudah tentu tidak sama dengan social budaya masyarakat yang lainnya. Apa yang cocok dimasa lampau belum tentu cocok dimasa kini, jadi bersifat dinamis. Suatu misal dimasa

2 Tri Marhaeni Pudji Astuti, 2011, Konstruksi Gender dalam Realita Sosial, Edisi Revisi, UNNES PRESS, Semarang, hlm.5.

3 Mansour Fakih, 1997, Analisis Gender \& Transformasi Sosial, Pustaka Pelajar, Yogyakarta, hlm. 8. lampau dimana perempuan tidak cocok menyetir mobil, namun dijaman sekarang hal seperti itu sudah tidak relevan lagi, bahkan dijaman sekarang banyak perempuan yang menyetir mobil, menjadi nakhoda, menjadi pilot dan lain sebagainya. Contoh lain, misalnya di bidang pendidikan, dimana dimasa lampau, hanya laki-laki yang berpendidikan tinggi, namun sekarang masalah pendidikan hak setiap orang tanpa memandang latar belakang social. Contoh lain yang sangat mudah dijumpai misalnya, dijaman lampau urusan domestik adalah urusan istri atau perempuan, sementara urusan publik adalah urusan laki-laki, namun dijaman sekarang baik urusan domestic maupun public adalah urusan laki-laki dan perempuan. Dengan demikian, gender adalah suatu konsep yang dibentuk berdasarkan sosial budaya suatu masyarakat setempat. Oleh karenanya gender itu tidak bersifat statis akan tetapi bersifat dinamis yaitu dapat berubah, diubah sesuai dengan perkembangan masyarakat dan kemajuan jaman, ilmu pengetahuan, teknologi dan lain sebagainya.

Sementara masih banyak kalangan yang merancukan antara apa itu kodrat dan apa gender. Dalam praktik kehidupan sehari-hari sering orang bilang bahwa kodrat perempuan adalah memasak, mengurus rumah, mengasuh anak, hal demikian tidak saja diucapkan oleh orang yang tidak berpendidikan, akan tetapi orang berpendidikan tinggi pun sering 
mengucapkan hal yang senada. Dengan demikian orang berpendidikan tinggi yang semestinya memberikan contoh kepada warga masyarakat tentang dua hal yang berbeda tersebut bahwa kodrat ciptaan Tuhan Yang Maha Kuasa sedangkan gender bentukan masyarakat. Kodrat sebagai ciptaan Tuhan tidak dapat diubah oleh manusia sementara gender akan mengikuti situasi dan kondisi dari masyarakat yang bersangkutan. Tingginya pendidikan seseorang tidak merupakan jaminan tentang pemahaman tentang konsep kodrat dan gender.

Sehubungan dengan konsep gender maka muncul persoalan apa sebenarnya ideologi gender tersebut. Ideologi sebenarnya merupakan suatu pandangan hidup atau paradigma dari seseorang atau suatu kelompok terhadap suatu hal. Ideologi adalah cara berfikir seseorang atau suatu golongan ${ }^{4}$. Ideologi gender adalah seperangkat ide-ide dan sistem nilai yang didasarkan pada determinisme biologis yang telah menghasilkan seksisme dan diskriminasi utamanya terhadap perempuan ${ }^{5}$. Adanya dua insan yakni laki-laki dan perempuan ini mencerminkan dua entitas yang saling membutuhkan dan melengkapi sebagai mitra kerja terhadap suatu hal. Dengan demikian maka adanya makna kesetaraan antara dua entitas tersebut. Makna setara tidak mesti "sama"

4 Departemen Pendidikan Nasional, 2002, Kamus Besar Bahasa Indonesia, Edisi Ketiga, Balai Pustaka, Jakarta, hlm 417.

5 http://www. koalisiperempuan. or.id/2011/05/04/i deologi-gender, diakses 17 Pebruari 2017. karena memang Tuhan menciptakan dua mahluk (manusia) laki-laki dan perempuan yang berbeda jenis kelamin dengan fungsinya masingmasing. Tuhan memang menciptakan perbedaan laki-laki dan perempuan, tetapi manusia atau kelompok membedakan perlakuan secara tajam dalam aspek-aspek kehidupan terutama dalam aspek hukum adat Bali. Dalam menjalankan fungsinya tentu saling membutuhkan satu sama lainnya sebagai suatu sistem. Perlu ditegaskan bahwa dalam kaitan dengan konsep gender tidak ada gender laki-laki dan gender perempuan, karena gender adalah suatu konsep peran-peran dan tanggung jawab laki-laki dan perempuan yang dapat berubah dan diubah karena keadaan sosial budaya suatu masyarakat. Kenyataan dalam masyarakat tidak sedikit orang yang merancukan konsep gender tersebut dan bahkan di kalangan akademisi tidak sedikit orang yang belum paham apa itu gender. Jadi intinya ideologi gender adalah mencerminkan makna kesetaraan antara laki-laki dan perempuan dalam aspek-aspek kehidupan. Terkait ideologi gender secara umum ada beberapa prinsip dasar ideologi gender yaitu : 6

1) Laki-laki dan perempuan samasama makhluk ciptaan Tuhan yang bebas dan mempunyai hak yang sama dalam kehidupan

6 Tim Penyusun Buku Ajar, 2016, Buku Ajar Gender dalam Hukum, Program Studi Ilmu Hukum, Fakulatas Hukum, Universitas Udayana, Pustaka Ekpresi, Tabanan, Bali, hlm. 16. 
domestik maupun publik. Ini menghasilkan konsep kesetaraan gender.

2) Kesadaran dan pemahaman bahwa tubuh perempuan adalah milik perempuan (bukan kekuasaan laki-laki) dengan demikian segala pengambilan keputusan menyangkut tubuhnya ada di tangan perempuan. Ini menimbulkan konsep otonomi perempuan.

3) Setiap tindakan terhadap perempuan tanpa persetujuan (tidak diingini) perempuan merupakan tindakan pemaksaan/ kekerasan/ketidak-adilan, hal mana patutmendapat perlawanan oleh perempuan.

Dalam kaitan makna gender dalam hukum adat maka akan dikemukakan beberapa konsep hukum adat yaitu Hasil Seminar Nasional 17 Januari 1975 yang dilaksanakan di Yogyakarta, salah satu dalam simpulannya menyebutkan bahwa hukum adat adalah hukum Indonesia asli yang tidak tertulis dalam bentuk perundang-undangan Republik Indonesia yang di sana sini mengandung unsur agama ${ }^{7}$. Dalam kepustakaan hukum adat belum ditemukan satu definisi atau konsep yang final dari pemerhati hukum adat. Sehubungan dengan hal itu ada beberapaahliyangmemberikan batasan tentang hukum adat. Adapun para ahli

7 Wayan P. Windia, Ketut Sudantra, 2006, Pengantar Hukum Adat Bali, Lembaga Dokumentasi \& Publikasi Fakultas Hukum Universitas Udayana, hlm.5 tersebut yaitu Soerojo Wignjodipoero mengemukakan bahwa hukum adat adalah komplek norma-norma yang bersumber pada perasaan keadilan rakyat yang selalu berkembang serta meliputi peraturan-peraturan tingkah laku manusia dalam kehidupan seharihari dalam masyarakat, sebagian besar tidak tertulis, senantiasa ditaati dan dihormati oleh rakyat karena mempunyai akibat hukum atau sanksi ${ }^{8}$. Sementara Soerjono Soekanto dalam Wiranata mengemukakan, hukum adat pada hakekatnya merupakan hukum kebiasaan, artinya kebiasaankebiasaan yang mempunyai akibat hukum (seinsollen). Berbeda dengan kebiasaan belaka, merupakan hukum adat adalah perbuatan-perbuatan yang diulang dalam bentuk yang sama yang menuju pada rechtsvardigeordening der samenleving 9 .

Ter Haar dalam Suriyaman Mustari mengatakan hukum adat adalah seluruh peraturan-peraturan yang ditetapkan dalam keputusankeputusan dengan penuh wibawa yang dalam pelaksanaannya "diterapkan begitu saja", artinya tanpa adanya keseluruhan peraturan yang dalam kelahirannya dinyatakan mengikat sama sekali ${ }^{10}$

8 Soerojo Wigjodipoero, 1973, Pengantar dan Asas-Asas Hukum Adat, Alumni Bandung, hlm. 5.

9 I Gede A.B.Wiranata, 2005, Hukum Adat Indonesia Perkembangannya dari Masa ke Masa, PT. Citra Aditya Bakti, Bandung, hlm. 24.

10 A. Suriyaman Mustari Pide, 2014, Hukum Adat, Dahulu, Kini, dan Akan Datang, Prenadamedia Group, Jakarta, hlm.4. 
Hukum adat adalah hukum yang tumbuh, berkembang dan mati sesuai dengan tingkat perkembangan masyarakat pendukungnya. Hukum adat Bali adalah aturan-aturan hukum yang berlaku dalam kehidupan seharihari bagi orang Bali Hindu yang berdiam atau tinggal di wilayah Bali. Sementara, Windia mengemukakan bahwa hukum adat Bali adalah kompleks norma-norma, baik dalam wujudnya yang tertulis maupun tidak tertulis, berisi perintah, kebolehan dan larangan yang mengatur kehidupan masyarakat Bali yang menyangkut hubungan antara sesama manusia, hubungan manusia dengan lingkungan alamnya dan antara manusia dengan Tuhannya $^{11}$. Oleh karena itu hukum adat Bali sudah barang tentu tidak sama atau berbeda dengan hukum adat di daerah lainnya, hal mana disebabkan karena masyarakat Indonesia terdiri beberapa suku bangsa. Sekalipun hukum adat Bali tidak sama dengan hukum adat daerah lainnya di Indonesia akan tetapi ada hal yang tidak berbeda dari hukum-hukum adat yang ada di Indonesia yakni nilai-nilai universal dari hukum adat itu sendiri. Adapun nilai-nilai yang dimaksud diuraikan oleh Soepomo yaitu asas gotong royong, fungsi sosial manusia, danmilik dalam masyarakat, asas persetujuan sebagai dasar kekuasaan umum, asas perwakilan dan permusyawaratan dalam sistem pemerintahan ${ }^{12}$.

11 Wayan P. Windia, Ketut Sudantra, op. cit. hlm. 6.

12 R. Soepomo, 1986, Bab-Bab tentang Hukum Adat, Pradnya Paramita, Jakarta, hlm. 20.
Hukum adat Bali adalah sangat dipengaruhi oleh budaya patriarkhi sehingga ideologi patriarkhi sangat kuat menjelma dalam hukum adat. Terkait dengan budaya patriarkhi, maka akan diuraikan tentang apa itu ideologi patriarkhi. Secara umum ideologi patriarkhi adalah suatu paradigma dimana kekuasaan berada di tangan laki-laki. Terkait dengan hal tersebut maka pada prinsipnya, ideologi patriarkhi menempatkan :

1. Laki-laki berada pada posisi superior terhadap perempuan.

2. Laki-laki sebagai makhluk yang berkuasa atau menentukan

3. Laki-laki sebagai pengambil keputusan $^{13}$.

Mencermati beberapa hal prinsip di atas maka dapat diketahui secara nyata dalam aturan hukum adat Bali. Dalam hukum waris secara tegas ditentukan bahwa ahli waris adalah keturunan lak-laki. Hal itu diatur hampir dalam setiap awigawig yang merupakan hukum dalam kehidupan masyarakat Bali Hindu. Awig-awig merupakan pedoman hidup dan menjalani kehidupan dalam bermasyarakat. Contoh beberapa awig-awig yang mengatur hal tersebut. Awig-awig Desa Pakraman Tonja, Denpasar mengatur tentang ahli waris dalam Pawos 53 yang berbunyi ahli waris luire :ha Pratisentana purusa, na Pratisentana (sentana rejeg), ca Sentana peperasan lanang/wadon. (artinya ahli waris adalah anak lakilaki, sentana rejeg dan anak angkat).

13 Tim Penyusun Buku Ajar, loc. Cit. 
Hal yang sama juga diatur dalam awigawig Desa Pakraman Susut, Buahan, Payangan, Gianyar pada Pawos 64 . Demikian juga dalam awig-awig Desa Adat Nusamara, Yehembang, Mendoyo, Jembrana yang diatur pada Pawos 53. Itulah beberapa contoh awig-awig yang mengatur bahwa anak atau keturunan laki-laki sebagai ahli waris. Ini mencerminkan bahwa hukum dibuat berdasarkan kepentingan laki-laki, karena memang dalam pembuatannya tidak melibatkan perempuan, sehingga hukum adat sangat seksis.

Anak perempuan ada kalanya dapat sebagai ahli waris tetapi harus memenuhi suatu persyaratan tertentu. Persyaratan dimana perempuan itu berstatus "sentana rajeg". Untuk dapat seorang perempuan berstatus sentana rajeg adalah harus melakukan perkawinan "nyeburin". Perkawinan nyeburin ini tidak dapat dilakukan oleh setiapperempuanBali,melainkanhanya dapat dilakukan oleh perempuan yang anak tunggal atau hanya mempunyai anak perempuan. Salah satu dari anak perempuannya harus sebagai pelanjut keturunan dengan melakukan perkawinan "nyeburin". Dengan perkawinan nyeburin, perempuan yang bersangkutan berstatus hukum laki-laki sehingga dapat sebagai ahli waris. Perempuan yang demikian disebut "sentana rajeg". Perempuan berstatus hukum laki-laki sifatnya terbatas yakni hanya dalam bidang keperdataan, sementara dalam bidang lainnya tetap sebagai perempuan pada umumnya.

\subsection{Implikasi Ideologi Gender Dalam Hukum Adat Bali}

Gender sebagai secara arfiah berarti jenis kelamin, akan tetapi jenis kelamin yang dimaksudkan adalah bukan sebagai ciptaan Tuhan melainkan sebagai konstruksi social budaya suatu masyarakat. Masyarakat yang membuat bahwa ini pantas untuk perempuan dan itu pantas untuk laki-laki, hal seperti ini sudah berlangsung sejak dahulu secara turun temurun hingga kini . Apa yang pantas untuk perempuan dan laki-laki pada masyarakat yang satu belum tentu pantas untuk masyarakat yang lainnya dan apa yang pantas dimasa lampau belum pantas dimasa kini. Oleh karena demikian maka gender dapat berubah dan diubah sesuai kondisi suatu masyarakat setempat. Jadi gender adalah bersifat dinamis, sifat dinamis itu karena merupakan konstruksi social budaya masyarakat. Sebagai bentukan manusia gender tidak bersifat statis dan tidak berlaku universal. Sementara hukum adat adalah juga merupakan konstruksi kelompok manusia atau sebuah lembaga, oleh karenanya hukum juga dapat diubah mana kala sudah tidak relevan lagi dengan perkembangan masyarakat tempat hukum itu bermuara. Hukum sebagai konstruksi masyarakat atau orang dalam hal ini difokuskan pada hukum adat dan secara khusus hukum adat 
Bali,juga tidak dapat berlaku universal. Hukum adat termasuk hokum adat Bali sangat kental dipengaruhi oleh budaya patriarkhi. Hukum adat Bali sangat kuat mengikat masyarakat Bali, dalam mana memposisikan lakilaki sangat tinggi, tiadanya keturunan laki-laki dalam suatu keluarga batih dapat menimbulkan pengangkatan anak, merubah status anak perempuan dengan perkawinan "nyeburin" dan bahkan sampai sang suami kawin lagi atau melakukan poligami. Yang terakhir dapat menimbulkan kekerasan psikologis bagi sang istri. Merubah status anak perempuan menjadi "sentana rajeg" itu diatur hampir disetiap awig-awig desa pakraman di Bali. Ini mencerminkan bahwa hukum adat sebagai konstruksi masyarakat laki-laki sebenarnya mempertahankan eksistensinya pada posisi yang superior dan berkuasa. Intinya hukum adat Bali jelas merupakan pencerminan ideologi patriarkhi.

Sehubungan dengan implikasi ideologi gender dalam hukum adat Bali yang menjadi focus dalam penelitian ini, hasil penelitian menunjukkan bahwa dapat digolongkan menjadi dua kelompok pandangan para responden. Kelompok pertama, memberi alasan bahwa hukum adat Bali sudah baik dan mencerminkan keunikan masyarakat Bali, dimana perempuan dalam keluarga khususnya dalam pengambilan keputusan tidak dilibatkan, semua keputusan dilakukan dan diambil atas kesepakatan laki-laki.
Dalam bidang waris anak perempuan tidak diperhitungkan dan ini sudah berlaku sejak dahulu. Jadi pandangan kelompokpertamatidakmencerminkan ideologi gender, sementara pandangan kelompok kedua, memberi alasan bahwa hukum adat sulit dirubah, untuk merubahnya membutuhkan kesadaran masyarakat. Kalau awig-awig belum mengatur hal-hal yang sesuai dengan perkembangan masyarakat dan peraturan perundang-undangan maka dapat dilakukan melalui perarem. Dari 20 orang responden, 18 orang termasuk pandangan kelompok yang pertama, dan hanya 2 orang termasuk pandangan kelompok kedua. Pandangan kelompok kedua ini sudah responsip gender berpikiran progresif serta relevan dengan tujuan Inpres No.9 Tahun 2000 tentang PUG. Jadi dapat dikatakan bahwa ideologi gender belum berimplikasi dalam hukum adat Bali. Faktor-faktor yang menjadi penghambat nya yaitu budaya hukum masyarakat Bali, hukum adat yang patriarkhis masih kuat mengikat kehidupan masyarakat Bali. Terkait hal itu Majelis Utama Desa Pakraman (MUDP) Propinsi Bali melalui Pesamuhan Agung III No. 1/ Kep/Psm-3/MDP Bali/X/2010 tanggal 15 Oktober merumuskan dalam salah satu keputusannya mencerminkan ideologi gender yakni kesetaraan khususnya dalam bidang hukum waris. Hal itu dapat diketahui dalam salah satu keputusannya yaitu dalam angka 4 sebagai berikut: anak kandung (laki- 
laki atau perempuan) serta anak angkat (laki-laki atau perempuan) berhak atas harta gunakaya orang tuanya, sesudah dikurangi sepertiga sebagai duwe tengah (harta bersama), yang dikuasai (bukan dimiliki) oleh anak yang nguwubang (melanjutkan swadharma atau tanggung jawab) orang tuanya. Keputusan MUDP tersebut sudah mencerminkan ideologi gender di dalamnya, akan tetapi itu belum merupakan hukum karena belum diimplementasikan dalam awig-awig oleh desa pakraman masing-masing sehingga belum mempunyai kekuatan mengikat akan tetapi dapat dipakai rujukan dalam hal terjadi masalah dalam bidang hokum waris.

Hal tersebut dikaji berdasarkan teori sistem hukum dari Lawrence M. Friedman ${ }^{14}$, bahwa hukum terdiri dari tiga komponen yaitu struktur hukum, substansi hukum dan budaya hukum, dimana dari ketiga komponen sistem hukum tersebut, hukum adat Bali belum mencerminkan ideologi gender baik dalam strukturnya, substansinya maupun budaya hukumnya. Ini berarti ideologi gender belum berimplikasi dalam hukum adat Bali.

\section{KESIMPULAN DAN SARAN}

Berdasarkan hasil penelitian dan pembahasan sebagaimana paparan di atas akhirnya dapat disimpulkan sebagai berikut:

14 Lawrence M Friedman, 1977, Law and Society: An Introduction, Printice, Hall New Jersey, hlm. 7
1. Gender merupakan hubungan laki-laki dan perempuan sebagai konstruksi sosial budaya masyarakat. Sementara makna ideologi gender adalah mengandung prinsip kesetaraan laki-laki dan perempuan sebagai mahluk sama-sama ciptaan Tuhan. Setara dalam bidang domestik maupun publik atau setara dalam segala aspek kehidupan, hal itu sangat berbeda dengan ideologi patriarkhi yang mempengaruhi hukum adat Bali yang mencerminkan makna tidak setara yaitu ada posisi superior dan imperior.

2. Ada dua kelompok pandangan responden terkait implikasi ideologi gender dalam hukum adat Bali yaitu, kelompok pertama, memberi alasan bahwa hukum adat Bali sudah baik dan mencerminkan keunikan masyarakat Bali, dimana perempuan dalam keluarga khususnya dalam pengambilan keputusan tidak diikutkan, semua keputusan diambil atas kesepakatan laki-laki. Dalam bidang waris anak perempuan tidak diperhitungkan dan faktor-faktor penyebabnya . Jadi pandangan kelompok pertama belum mencerminkan ideologi gender umum , sementara pandangan kelompok kedua, memberi alasan bahwa hukum adat sulit 
diubah, untuk mengubahnya membutuhkan kesadaran masyarakat. Kalau awig-awig belum mengatur hal-hal yang sesuai dengan perkembangan. Pandangan kelompok kedua responsif gender dan sudah berpikiran progresif dan sudah mencerminkan ideologi gender umum. Jadi ideologi gender secara umum ternyata belum bisa berpengaruh dalam hukum adat Bali baik dalam hukum keluarga maupun hukum waris, factorfaktor penyebabnya karena budaya hukum masyarakat Bali dan hukum adat Bali yang patriarkhis sangat kuat mengikat kehidupan masyarakat Bali.

\section{DAFTAR PUSTAKA}

Amiruddin, Zainal Asikin, 2008, Pengantar Metode Penelitian Hukum, PT RajaGrafindo Persada, Jakarta.

Departemen Pendidikan Nasional, 2002, Kamus Besar Bahasa Indonesia, Edisi Ketiga, Balai Pustaka, Jakarta.

Fakih, Masour, 1997, Analisis Gender \& Transformasi Sosial, Pustaka Yogyakarta.

Handayani, Trisakti, Sugiarti, 2002, Konsep dan Teknik Penelitian Gender, Editor Surya Dharma, UMM Press, Universitas Muhammadiyah, Malang.

Pide, A. Suriyaman Mustari, 2014, Hukum Adat, Dahulu, Kini, dan
Akan Datang, Prenadamedia Group, Jakarta.

Soepomo,R., 1986, Bab-Bab tentang Hukum Adat, Pradnya Paramita, Jakarta.

Wignjodipuro, Surojo, 1973, Pengantar Dan Asas-Asas Hukum Adat, Gunung Agung, Jakarta.

Windia, I Wayan P., Ketut Sudantra, 2006, Pengantar Hukum Adat Bali, Lembaga Dokumentasi dan Publikasi Hukum, Fakultas Hukum Universitas Udayana.

Wiranata, I Gede A.B., 2005, Hukum Adat Indonesia Perkembangannya dari Masa ke Masa, PT. Citra Aditya Bakti, Bandung. Instruksi Presiden Republik IdonesiaNo.9Tahun2000tentang Pedoman Pengharusutamaan Gender Dalam Pembangunan Nasional. 